\title{
Hypothenar hammer syndrome: a case series and literature review
}

\author{
Hipotenar çekiç sendromu: Olgu serisi ve literatürün gözden geçirilmesi
}

\author{
Mehmet Şükrü Şahin, MD., ${ }^{1}$ Tuna Özyürekoğlu, MD., ${ }^{1}$ Gökhan Çakmak, MD. ${ }^{2}$ \\ ${ }^{1}$ Christine M. Kleinert Institute For Hand and Microsurgery, Louisville, USA \\ ${ }^{2}$ Department of Orthopedics and Traumatology, Medical Faculty of Başkent University, \\ Alanya Training and Medical Research Center, Antalya, Turkey
}

\begin{abstract}
Objectives: This study aims to report our experience regarding patients who were surgically treated due to hypothenar hammer syndrome and review the related literature.

Patients and methods: The study included 11 hands of eight patients (5 males, 3 females; mean age 48 years; range 29 to 60 years) who underwent surgery due to hypothenar hammer syndrome between September 2004 and March 2013. Mean follow-up period was 50 months (range 3-103 months). The time of symptom onset, occupational history, and detailed physical examination findings were recorded. Surgery was performed under sedation and axillary anesthesia. Distal segment of the forearm, all thrombosed segments of the Guyon and superficial arch were removed. Reconstruction of the ulnar artery and the superficial arch was performed using vein grafts obtained from the forearm.
\end{abstract}

Results: While all patients' dominant hand was affected, both hands were affected in three patients. All patients complained of pain and color change in one finger or multiple fingers. While minimal amputation and debridement of fingertip pulp was performed in two patients, all other patients recovered uneventfully. Patency of the ulnar artery was uneventful at follow-up in five of the eight patients, whereas three patients were performed revision surgery for a new vein graft. Most patient complaints resolved during the follow-up period.

Conclusion: Hypothenar hammer syndrome is a disease of the upper extremities that should be considered in patients with digital ischemia, and a history of manual labor and smoking. Although this disease can be treated with conservative therapy, advance-stage patients who fail to respond to conservative treatment can be treated surgically with vein grafts.

Keywords: Arterial reconstruction; digital ischemia; hypothenar hammer syndrome; ulnar artery; vein graft.

\section{ÖZ}

Amaç: $\mathrm{Bu}$ çalışmada hipotenar çekiç sendromu nedeniyle cerrahi tedavi yapılan hastalarla ilgili deneyimlerimiz sunuldu ve ilgili literatür gözden geçirildi.

Hastalar ve yöntemler: Çalışmaya Eylül 2004 - Mart 2013 tarihleri arasında hipotenar çekiç sendromu nedeniyle cerrahi geçiren sekiz hastanın (5 erkek, 3 kadın; ort. yaş 48 yıl; dağılım 29-60 yıl) 11 eli dahil edildi. Ortalama takip süresi 50 aydı (dağılım 3-103 ay). Semptom başlama zamanı, mesleki öykü ve ayrıntılı fizik muayene bulguları kaydedildi. Cerrahi sedasyon ve aksiller anestezi altında gerçekleştirildi. Ön kolun distal kısmı, Guyon ve yüzeyel arktaki tüm tromboze kısımlar çıkartıldı. Ulnar arter ve yüzeyel ark rekonstrüksiyonları ön koldan alınan ven greftleri kullanılarak yapıldı.

Bulgular: Hastaların tamamının dominant eli etkilenirken üç hastada iki el etkilenmişti. Tüm hastalar bir veya birkaç parmağında ağrı ve renk değişikliğinden yakındı. İki hastanın parmak ucu pulpasından minimal amputasyon ve debridman yapılırken diğer hastaların tamamı sorunsuz iyileşti. Takiplerinde, sekiz hastanın beşinde ulnar arter açıklığı sorunsuz iken üç hastaya yeni ven grefti için revizyon cerrahisi yapıldı. Hastaların yakınmalarının çoğu takip sürecinde ortadan kalktı.

Sonuç: Hipotenar çekiç sendromu, parmak iskemisi ve el işleri ile sigara öyküsü olan hastalarda dikkate alınması gereken, üst ekstremitelerin bir hastalığıdır. Bu hastalık konservatif olarak tedavi edilebilse de konservatif tedaviye yanıt vermeyen ileri dönem hastalar ven greftleri ile cerrahi olarak tedavi edilebilir.

Anahtar sözcükler: Arter rekonstrüksiyonu; parmak iskemisi; hipotenar çekiç sendromu; ulnar arter; ven grefti.

\footnotetext{
- Received: January 28, 2014 Accepted: November 11, 2014

- Correspondence: Mehmet Sükrü Șahin, MD. Christine M. Kleinert Institute For Hand and Microsurgery 225 Abraham Flexner Way, Suite 850 Louisville, 40202 KY, USA. Tel: +90 533-35752 75 Fax: +90 242 - 5115563 e-mail: msukrusahin@yahoo.com

- Presented at the $23^{\text {th }}$ Orthopedics and Traumatology Congress, October 29 - November 03, 2013, Antalya, Turkey.
} 
Hypothenar hammer syndrome (HHS) is a rare but treatable disease characterized by an aneurysm or occlusion of the arteries of the hand, typically the ulnar artery. Hypothenar hammer syndrome is most commonly observed in people exposed to acute blunt, vibratory, or repetitive chronic trauma to the hypothenar muscles like in carpal tunnel. ${ }^{[1-4]}$ Hypothenar hammer syndrome is difficult to diagnose and when not treated timely, may lead to serious complications including amputation. ${ }^{[1]}$ Of note, ischemia associated with HHS is reversible. ${ }^{[5]}$ In those with occupations that necessitate regular use of hammers, repeated trauma to the hypothenar muscles may damage the superficial arch branch of the ulnar artery. ${ }^{[6]}$ Digital emboli from an ulnar artery thrombosis may cause ischemia or necrosis in the fingers. ${ }^{[7]}$

The clinical presentation of HHS consists of color change in the hand or fingers, cold intolerance, minor ulcerations, and small necrotic areas on the fingertips. ${ }^{[8]}$ The severity of symptoms depends on the extent of the occluded segment, and the presence of collaterals between the deep and superficial palmar arches. ${ }^{[2]}$ Primary management of the disease consists of conservative treatment. In patients with complaints that persist despite conservative treatment, medical treatment is an option, and when medical treatment is ineffective, surgical treatment should be recommended. Proximal cervicothoracic sympathectomy or peripheral periarterial sympathectomy may be added to these treatments. ${ }^{[8,9]}$ In this study, we aimed to report our experience regarding patients who were surgically treated due to HHS and review the related literature.

\section{PATIENTS AND METHODS}

This retrospective study included eight HHS patients ( 5 males, 3 females; mean age 48 years; range 29 to
60 years) who were treated for HHS using artery reconstruction via vein grafts at Christine M. Kleinert Institute between September 2004 and March 2013. Written informed consents were obtained from all the participants. Three patients with thenar hammer syndrome and a radial artery thrombus who presented with similar complaints were not included. Among the eight HHS patients, reconstruction using reversed vein grafts following thrombus excision was performed by the same surgeon in 11 upper extremities. Mean duration of follow-up was 50 months (range 3-103 months). The time of onset of the first symptom, occupational history, and detailed physical examination findings were recorded. Visual analog scale (VAS) pain scores were recorded preoperatively and one month postoperatively. Preoperative Allen test was administered and cold intolerance was evaluated in all patients. Diagnosis of HHS was confirmed using upper extremity angiography (Figures 1 and 2). Conservative treatment was initiated in all patients. Smoking and drinking coffee were prohibited. Patients were requested to avoid labor that strains the hand. Patients who did not respond to conservative treatment during a mean three weeks underwent surgical treatment. Criteria for surgery included progressive digital ischemia, non-healing painful ulcers, and progressive color change in the fingers despite conservative treatment.

All surgical procedures were performed under sedation and axillary anesthesia. An S-type incision was made from the distal portion of the forearm over the ulnar area to the wrist and the palmar arch using a 3x surgical loupe (Figure 2a). The canal of Guyon and the surrounding area were explored. Separation of the ulnar artery from the ulnar nerve was started slightly above the level of the wrist. The probable thrombosed segment was located and marked
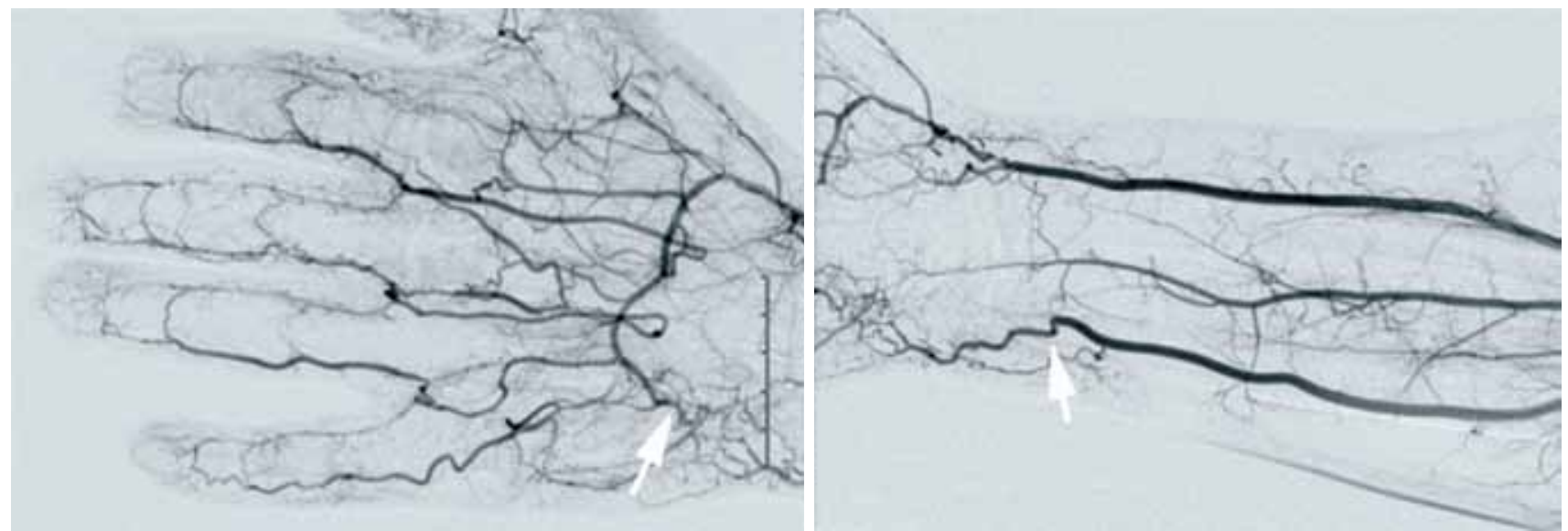

Figure 1. Upper extremity angiography: a stenosis or occlusion (arrows) is visible at Guyon canal. 
proximally and distally (Figure $2 \mathrm{~b}$ ). Thrombosed segments of all the vessels of the forearm, the canal of Guyon, the superficial palmar arch, and the fingers were removed after they were measured (Figure 3a, b). To prevent possible flow problems, the grafts were reversed and reconstruction of the ulnar artery and superficial arch was performed using a microscope. Similarly, reconstruction of the arteries of the fingers was performed after removing the thrombotic segment of the digital arteries and collecting additional vein grafts. Patency of the anastomosis and blood flow through the vein grafts were assessed, and the surgery was complete after sufficient capillary refill was observed (Figure 3c). Postoperatively, the patients used salicylic acid $81 \mathrm{mg} \mathrm{d}^{-1}$ for three weeks. All the patients were followed-up two weeks, six weeks, six months, and one year after surgery. During the early follow-up period, the patency of the ulnar arteries was assessed using the Allen test and Doppler ultrasonography. During follow-up, upper extremity angiography was repeated in three patients due to insufficient blood flow.

\section{Statistical analysis}

IBM SPSS for Windows version 19.0 software program (IBM Corp., Somers, NY, USA) was used for all statistical analyses. All data were analyzed using Pearson's correlation test.

\section{RESULTS}

While the dominant hand was affected in all eight patients, both hands were affected in three patients.
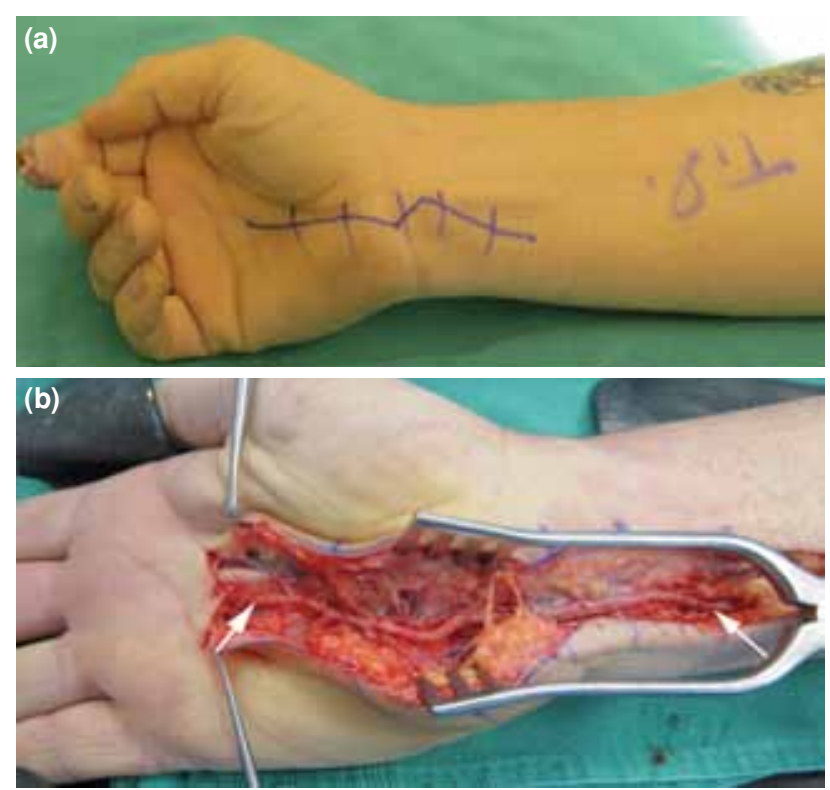

Figure 2. (a) Incision marking during operation. (b) View of thrombosed ulnar artey segment including Guyon canal and superficial palmar arch (arrows).
All patients had complaints of pain and color change in at least one finger. Five patients were smoking cigarettes at the time of the first physical examination. One female patient had a four-year history of migraine and was using rizatriptan, and presented with bilateral involvement of the ulnar arteries. In total, seven patients had a history of repeated chronic trauma while a heavy object had fallen on the hand of one patient. Comorbidity among the patients was as follows: diabetes mellitus: $n=2$; rheumatoid arthritis: $n=1$; migraine: $n=1$; anxiety syndrome: $\mathrm{n}=3$; hyperlipidemia: $\mathrm{n}=1$; hypertension: $n=2$; smoking: $n=5$. Angiography showed arterial occlusions at different levels of the hand and wrist. All patients had a thrombus of the ulnar artery which was surgically removed. Six patients recovered without complications, whereas two required minimal fingertip amputation and debridement.

Mean healing time of the ulcers was five weeks (range 3-9 weeks). In nearly all patients, pain in the hand and fingers was relieved after surgery. According to VAS pain scores, severity and level of pain were lower after surgery. Mean preoperative VAS pain score was 7 (range 4-10) compared to 1.3 (range 0-3) after surgery and the difference was statistically significant $(\mathrm{p}=0.01)$. Re-occlusion of the ulnar artery occurred in three patients during follow-up: one patient underwent a second operation 15 days after the initial surgery since a thrombus developed in the vein graft, one patient with
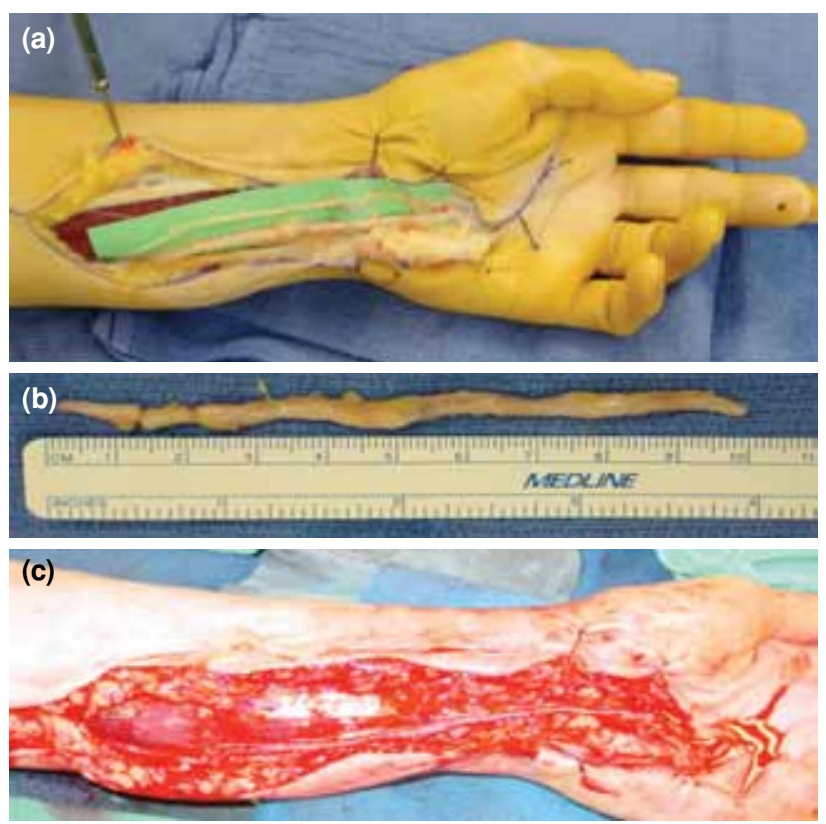

Figure 3. (a) Intraoperative view of thrombozed ulnar artery of a patient with hypothenar hammer syndrome, (b) excised thrombozed segment and (c) ulnar artery after reconstruction. 
reduced blood flow six months after surgery did not require any intervention since there were no clinical complaints, and one patient developed a thrombus 19 months after surgery and completely recovered after a second operation during which reconstruction was performed using a vein graft. The majority of the patients' symptoms resolved during follow-up after surgery.

\section{DISCUSSION}

Hypothenar hammer syndrome is caused by repeated trauma to the hypothenar muscles. ${ }^{[2]}$ Although the literature reports particularly male patients, female patients have also been reported. Patients with HHS complain of color and sensation changes in the fingers. In advanced cases, finger necrosis, ulceration, and infection may be present. For long-term treatment success, patients must avoid activities that trigger the disease. ${ }^{[1]}$ Timely diagnosis of HHS is important for minimizing potential complications. ${ }^{[5]}$ There is no consensus concerning the diagnosis and treatment of HHS. In addition, the diagnostic algorithm is complex because of the disease's rarity and wide range of symptoms. ${ }^{[5,6]}$ In most patients, recovery and symptom relief may be achieved via conservative treatment. Conservative treatment approaches include calcium antagonists and type A botulinum toxin, beta-blockers, cilostazol, nifedipine, antithrombotic agents, and thermal therapies. ${ }^{[10]}$ Surgery is also a treatment option in patients who do not respond to conservative treatment. Ultrasonography, computed tomography, and magnetic resonance imaging can be used to aid diagnosis; however, direct angiography is the gold standard for diagnosing HHS. ${ }^{[1,2]}$

In our patients, we performed surgical treatment after evaluating clinical symptoms and results of extremity angiography. Based on earlier reports, superficial forearm veins, such as the cephalic and basilic, were used as vein grafts since harvesting these veins is not challenging and causes minimal morbidity. ${ }^{[11]}$ Temming et al. ${ }^{[9]}$ treated patients using the descending branch of the lateral femoral circumflex artery as an arterial graft and reported that the graft is superior to conventional vein grafts. As their study included only two patients, we do not think they provided sufficient evidence for reaching a conclusion. One of the fundamental goals of surgery is to reinforce blood flow to the hand and affected fingers ${ }^{[8]}$ In patients with connective tissue disease, peri-arterial sympathectomy can facilitate both healing of ulcers and subjective recovery. ${ }^{[12]}$ While peri-arterial sympathectomy significantly improves digital ischemia in patients with autoimmune disorders, the technique has only a minimal effect on digital ischemia and ulcers in patients with atherosclerotic vascular disease. ${ }^{[13]}$ Artery reconstruction is essential in patients with occluded vessels in order to establish blood flow. ${ }^{[8,11,14]}$ To the best of our knowledge, the literature does not include any reports of HHS due to use of rizatriptan, and we believe the present study is the first to report a case of HHS involving both hands that was caused by the use of Maxalt.

Most of the patients in this study returned to their normal daily activities, and experienced recovery of the tropic changes and ulcers in their hand and fingers following surgery. The recurrence of the disease in three patients at two weeks, six months and 16 months after surgery indicates that the risk of thrombus formation is present at any time after surgery. In the three patients with recurrence, symptoms resolved again via reconstruction with vein grafts. In such cases, the importance of eliminating factors that trigger the disease after surgery, such as smoking, is apparent for the success of treatment.

The primary limitation of the present study is that it was not a controlled study; however, to the best of our knowledge, no controlled studies were reported in the literature on HHS due to the disease's rarity. ${ }^{[6,15]}$ Preoperative symptoms in this study's patients, including ischemic pain, skin necrosis, and cold intolerance, resolved and hand function significantly improved in nearly all the patients after surgery. Based on our findings, we think that treating HHS patients, who do not respond to conservative treatment, by surgically removing the thrombosed segment and reconstructing the segment with a vein graft, may provide long-term positive outcomes.

\section{Declaration of conflicting interests}

The authors declared no conflicts of interest with respect to the authorship and/or publication of this article.

\section{Funding}

The authors received no financial support for the research and/or authorship of this article.

\section{REFERENCES}

1. Nitecki S, Anekstein Y, Karram T, Peer A, Bass A. Hypothenar hammer syndrome: apropos of six cases and review of the literature. Vascular 2008;16:279-82.

2. Dreizin D, Jose J. Hypothenar hammer syndrome.Am J Orthop (Belle Mead NJ) 2012;41:380-2.

3. Ablett CT, Hackett LA. Hypothenar hammer syndrome: case reports and brief review. Clin Med Res 2008;6:3-8.

4. Çiftdemir M, Çopuroğlu C, Özcan M, Çavdar L. Carpal tunnel syndrome in manual tea harvesters. Eklem Hastalik Cerrahisi 2013;24:12-7. 
5. Swanson KE, Bartholomew JR, Paulson R. Hypothenar hammer syndrome: a case and brief review. Vasc Med 2012;17:108-15.

6. Yuen JC, Wright E, Johnson LA, Culp WC. Hypothenar hammer syndrome: an update with algorithms for diagnosis and treatment. Ann Plast Surg 2011;67:429-38.

7. Walgenbach $\mathrm{KJ}$, Krishnamurthy $\mathrm{A}$, Walgenbach-Brünagel G, Lee WP. An anomalous muscle predisposing to the development of hypothenar hammer syndrome. Plast Reconstr Surg 2009;124:197-9.

8. Savvidou C, Tsai TM. Long-term results of arterial sympathectomy and artery reconstruction with vein bypass technique as a salvage procedure for severe digital ischemia. Ann Plast Surg 2013;70:168-71.

9. Temming JF, van Uchelen JH, Tellier MA. ypothenar hammer syndrome: distal ulnar artery reconstruction with autologous descending branch of the lateral circumflex femoral artery. Tech Hand Up Extrem Surg 2011;15:24-7.

10. Dean SM, Satiani B. Three cases of digital ischemia successfully treated with cilostazol. Vasc Med 2001;6:245-8.

11. Namdari S, Weiss AP, Carney WI Jr. Palmar bypass for digital ischemia. J Hand Surg Am 2007;32:1251-8.

12. Zook EG, Kleinert HE, Van Beek AL. Treatment of the ischemic finger secondary to digital artery occlusion. Plast Reconstr Surg 1978;62:229-34.

13. Hartzell TL, Makhni EC, Sampson C. Long-term results of periarterial sympathectomy. J Hand Surg Am 2009;34:1454-60.

14. Lifchez SD, Higgins JP. Long-term results of surgical treatment for hypothenar hammer syndrome. Plast Reconstr Surg 2009;124:210-6.

15. Cooke RA. Hypothenar hammer syndrome: a discrete syndrome to be distinguished from hand-arm vibration syndrome. Occup Med (Lond) 2003;53:320-4. 